\title{
On the Madelung Part of Lattice Energy
}

\author{
New Pathways to use it as a Tool in Solid State Chemistry (Part 1) \\ Rudolf Hoppe \\ Institut für Anorganische und Analytische Chemie der Justus-Liebig-Universität, \\ Heinrich-Buff-Ring 58, D-35392 Gießen
}

Z. Naturforsch. 50a, 555-567 (1995); received December 16, 1994

Herrn Professor Dr. Dr. h.c. E. Wicke zum 80. Geburtstag

Zeiten und Winde des Lebens verwehen uns Menschen im Raumedoch der Erinnerung Bild bindet für immer das Herz.

The Born-Haber Cycle (BHC) is critically reviewed, the origin of severe limitations in its application is shown. Partly this is based on the construction of the third step, partly it is connected with the fact that most of the "classical" anions of inorganic chemistry are instable, "unobservable" gaseous entities. The Madelung Part of Lattice Energy, MAPLE*, is extentionally analyzed (e.g. $\mathrm{TiO}_{2}$ ) to demonstrate that the similarity of thermodynamical properties like $\Delta H_{298}^{\circ}$ of all modifications, reflected in MAPLE, is non-trivial. The analogous analysis with e.g. $\mathrm{BaTiO}_{3}$ proves that neither the classical "central ion" (here $\mathrm{Ti}^{4+}$ ) nor the "completing" cation (here $\mathrm{Ba}^{2+}$ ) but the "anions" coordinating the last mentioned cation $\mathrm{BaO}$ gain energy and, in this sense, "stabilize" the complex. Even simple compounds (e.g. $\mathrm{A}-\mathrm{La}_{2} \mathrm{O}_{3}$ ) show surprising geometrical arrangements, in striking contrast to often used but simple minded concepts like "Bond Length/Bond Strength" and its derivatives like CHARDI, whereas such "oddities" are explained by MAPLE. The application of the theorem of additivity of MAPLE (MAPLE $E_{\text {polynary }}=\sum$ MAPLE binary $)$, that passes even in the case of hydrates, and its limitations are discussed. Guided by MAPLE, surprisingly complicated structures (e.g. $\mathrm{Cs}_{2} \mathrm{Li}_{3} \mathrm{I}_{5}$ ) of polynary derivatives of structurally exceedingly simple binary compounds become "understandable". If "molecular" entities like $\mathrm{SO}_{3}$ are involved, limitations can be excluded using "increments". Last not least, MAPLE is the first known guide to a multi-dimensional but strict scheme of characterisation of Solid State Structures in the sense of Linné's ideas, based on geometrical facts only.

\section{Introduction}

Chemistry is based on experience. So, light and shadow are combined: At any time a material or a reaction can be observed which had never been realized before, nobody would have expected or is in striking contrast to all we know today. But, to participate actively in this field requires knowledge, generally accepted or, more dangerously, based on own experience. It is both, which anyway necessarily creates prepossesions, and so perhaps is abrogating creativity.

With Solid State Chemistry everything is more complicated. We use, e.g., venerable chemical formulas, created ingeniously by J. J. Berzelius long ago,

\footnotetext{
* With crystal structures used here simply to indicate how to deal with MAPLE, citation is restricted to the year of publication, e.g. [1962]. It is easy to find the data in detail by Structure Reports or, after 1990, by Chemical Abstracts Index.
}

Reprint requests to Prof. Dr. Drs. h.c. R. Hoppe. useful still for molecules. But in case of solids, even simple formulas like $\mathrm{CsLiCl}_{2}$ [1] do not allow to make a first guess concerning the structural constitution. Here, e.g., this chloride is surprisingly isotypic with the oxide $\mathrm{K}\left[\mathrm{CoO}_{2}\right]$ [2]. This cannot be expected or described using such simple formulas.

Even the more intimate formulation $\mathrm{Cs}\left[\mathrm{Li}(\mathrm{Cl} 1)_{4 / 4}(\mathrm{Cl} 2)\right]$ gives no hint to the steric arrangement of the constituents. One has either to know or to tell a long story on a chessboard-like layer $(\mathrm{Cl} 1)$, where all fields are centered by $\mathrm{Li}$ (motif: up and down instead of black and white) with $\mathrm{Cl} 2$ "riding" on $\mathrm{Li}$, thus completing the squares of $4 \mathrm{Cl} 1$ beneath/ above each $\mathrm{Li}$ to sheets of tetragonal pyramids, connected via common edges/corners, with Cs occupying holes within the stacking of those layers.

We need urgently help in our attempts to understand what we believe to know, and to foresee what might happen when we deal with new pathways of synthesis. In addition, our game is far away from "Science" in the literal meaning, because there exists no "critical" or even "simple but complete" list of the present state of knowledge [3], and no generally appli- 
cable systematic scheme of order at all [4]. In addition, many of our basic terms are ill-defined or not at all. What does "complex" really mean? Where is a generally accepted definition of the term coordination number $(\mathrm{CN})$ ? Everybody should know that there are no "ionic" or "atomic" or "covalent" radii at all, but if we use such terms daily, what is it we are referring to?

In dealing here with the Born-Haber-Cycle (BHC) and lattice energy and mainly with the Madelung Part of Lattice Energy, MAPLE [5], it is intended to show by examples why and how we can use this concept to create new aspects of Solid State Chemistry and its mysteries today, to the benefit of the hunters for new materials and for a deeper understanding of the "known" facts.

\section{Starting Remarks on the Born-Haber-Cycle}

The term MAPLE [5] is connected with the BHC (Figure 1). This cycle is an illustrative subject of textbooks and helpful in chemical education. Unfortunately, three deficits are attached to it, in a chemical as well as in a physical sense:

1) In Solid State Chemistry the term "complex" is still used despite its age (A. Werner, 1893 [6]) and vague definition. So, if we regard e.g. the formation of $\mathrm{K}_{2}\left[\mathrm{PtCl}_{6}\right]$ from the elements, which is one of the classical examples of Werner, steps $\mathrm{B} 1$ and $\mathrm{B} 2$ remain principally unaltered like with CsF. But now step B3 does not correspond to step B3 in Fig. 1 and can be definied in 4 ways:

$\left.\begin{array}{l}\text { B3a } \\ \text { B3b } \\ \text { B3c } \\ \text { B3d }\end{array}\right\}\left\{\begin{array}{c}2 \mathrm{~K}_{\mathrm{g}}^{+} \\ + \\ \mathrm{Pt}_{\mathrm{g}}^{4+} \\ + \\ 6 \mathrm{Cl}_{\mathrm{g}}^{-}\end{array}\right\}\left\{\begin{array}{l}\rightarrow 2 \mathrm{~K}_{\mathrm{g}}^{+}+\left[\mathrm{PtCl}_{6}\right]_{\mathrm{g}}^{2-} \\ \rightarrow \mathrm{K}_{2}\left[\mathrm{PtCl}_{6}\right]_{\mathrm{g}} \\ \rightarrow 2 \mathrm{KCl}_{\mathrm{g}}+\mathrm{PtCl}_{4 \mathrm{~g}} \\ \rightarrow 2 \mathrm{KCl}_{\text {solid }}+\mathrm{PtCl}_{4 \text { solid }}\end{array}\right\} \begin{aligned} & \text { with } \Delta G_{\mathrm{T}}^{\circ} \\ & \text { (B3a }-\mathrm{d}) .\end{aligned}$

Correspondingly we have 4 additional steps B4a)B4d), finally leading from these "intermediate" entities (e.g. B3a: $2 \mathrm{~K}_{\mathrm{g}}^{+}+\left[\mathrm{PtCl}_{6}\right]_{\mathrm{g}}^{2-}$ ) with e.g. step $\Delta G_{\mathrm{T}}^{\circ}(4 \mathrm{a})$ to $\mathrm{K}_{2}\left[\mathrm{PtCl}_{6}\right]_{\text {solid }}$. So $\Delta G_{\mathrm{T}}^{\circ}(\mathrm{B} 3 \mathrm{a})$ is one way to define the "energy of complex formation", as well as with $\Delta G_{\mathrm{T}}^{\circ}$ (B3 b). But in the last two cases it would be $\Delta G_{\mathrm{T}}^{\circ}(\mathrm{B} 4 \mathrm{c})$ or $\Delta G_{\mathrm{T}}^{\circ}(\mathrm{B} 4 \mathrm{~d})$, respectively, which should represent the foresaid term. Obviously there is no systematic investigation to decide which one of these, or other possibilities, would be the most convenient one.
BORN-HABER-CYCLE (CsF)

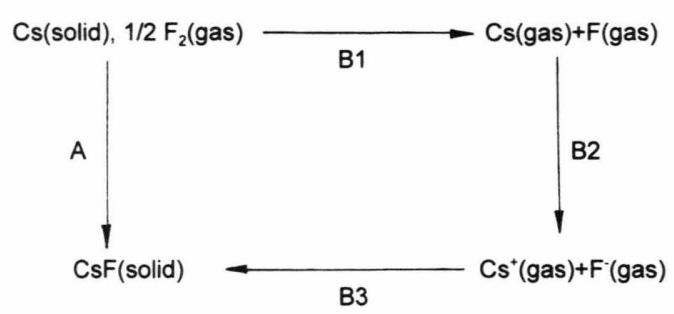

Fig. 1. BHC(CsF) $\left(A=\Delta G_{0}^{\circ} \approx \Delta H_{298}^{\circ}\right.$ only, if all components involved are solids).

2) Much more important is a general weakness of the $\mathrm{BHC}$, which is connected with the physical design of the steps:

a) Always, even in case of compounds like CsF, step A (Fig. 1) naturally is "sodden" deeply by the 3 main types of "Chemical Bonding", namely "metallic" $(\mathrm{Cs})$, "covalent" $\left(\mathrm{F}_{2}\right)$, "ionic" $(\mathrm{CsF}),-$ and even van der Waals forces [7].

b) In striking contrast to this complicated situation,

- step B1 is an act of "social fairness": equal "starting positions" for anyone involved;

- step B2 is an illustrative example of the simple but dangerous motto "take and give",

c) so that in accounting for such luxuries we have to pay with

- step B3 for all the complications connected with step A.

The usual way to overcome this problem is to break step B3 as: $\mathrm{B} 3=E_{\text {latt }}=E_{\text {Mad }}+E_{\mathrm{Born}}+E_{\mathrm{w}}+E_{\mathrm{pP}}+\ldots+E_{\text {corr }}$, where $M_{\text {Mad }}$ corresponds to MAPLE, $E_{\text {Born }}$ accounts for Born's repulsion, $E_{\mathrm{w}}$ for van der Waals attraction, $E_{\mathrm{PP}}$ for interactions of the sort ion/dipole, dipole/dipole etc. Last not least $E_{\text {corr }}$ equalizes both sides of the equation, the left one is principally known by experiments, and therefore acts as a fine indicator of the accuracy of the model used in calculating the right side [8].

3) But the most important and terrible limitation of the BHC is connected with step B2 (Fig. 1), insinuating that all the "chemically used" ionic species involved here are observable. This is not the case, as is known from $\mathrm{O}^{2-}$ for a long time [9]. The same holds [10] for "well-known" chemical species like $\mathrm{CO}_{3}^{2-}$, $\mathrm{PO}_{4}^{3-}, \mathrm{SiO}_{4}^{4-}$ etc. as gaseous entities - they all do not exist! Therefore the BHC can scarcely be used, because the thermochemical values necessary for step B3 are in many cases principally unknowable (see Table 1). It is this, why, already when starting to deal 
Table 1. On "anions" in solids, compared with analogues in gaseous state ${ }^{a}$.

\begin{tabular}{llll}
\hline Anion & $\begin{array}{l}\text { Observed Available/ } \\
\text { as } \\
\text { entities }\end{array}$ & $\begin{array}{l}\text { Confirmed } \\
\text { known }\end{array}$ & $\begin{array}{l}\text { in melts/ } \\
\text { solutions }\end{array}$ \\
\hline $\mathrm{H}^{-}, \mathrm{F}^{-}, \mathrm{I}^{-}, \mathrm{Au}^{-}$ & + & + & + \\
$\mathrm{O}_{2}^{-}, \mathrm{S}_{2}^{-}, \mathrm{O}_{3}^{-}, \mathrm{N}_{3}^{-}$ & + & + & $\mathrm{N}_{3}^{-}$ \\
$\mathrm{O}^{2}, \mathrm{Te}^{2-}, \mathrm{N}^{3}$ & + & - & - \\
$\mathrm{HO}^{-}, \mathrm{NO}_{2}^{-}, \mathrm{ClO}_{3}^{-}, \mathrm{ClO}_{4}^{-}$ & + & + & + \\
$\mathrm{BF}_{4}^{-}, \mathrm{PF}_{6}^{-}$ & + & + & + \\
$\mathrm{CO}_{3}^{2}, \mathrm{BO}_{3}^{3-}, \mathrm{SiO}_{4}^{4-}$ & + & - & + \\
{$\left[\mathrm{PtCl}_{6}\right]^{2-},\left[\mathrm{AlF}_{6}\right]^{3-}$ etc. } & + & - & + \\
$\mathrm{But}_{\mathrm{BO}}^{-}, \mathrm{BlO}_{2}^{-}$ & - & + & - \\
\hline
\end{tabular}

a Please, note:

1) All simple multiply charged anions $\mathrm{M}^{p-}$ and $\left[\mathrm{ML}_{z}\right]^{p-}$ with $p>1$ are, like $\mathrm{O}^{2-}$, "non-existent" as gaseous species.

2) It is still unknown, whether species like ${ }^{-} \mathrm{O}_{2} \mathrm{C}-\left(\mathrm{CH}_{2}\right)_{n}-$ $\mathrm{CO}_{2}^{-}$might exist, when $n$ is sufficiently large. Correspondingly, the same may hold for anions like e.g. ${ }^{-} \mathrm{F}_{5} \mathrm{Pt}-$ $\left(\mathrm{MF}_{4}\right)_{n}-\mathrm{PtF}_{5}^{-}$with appropriate high values of $n$. Such anions have never been obtained in solids up to now.

3) It is still unknown, whether anions like $\left[\mathrm{O}_{3} \mathrm{SOMnO}_{3}\right]^{-}$ and analogues might be observed when time comes. These could be stable as gaseous species, so that thermochemical data might be obtained.

b Characterized by single crystal structures.

c Thermochemical data known, knowable or calculated by "strict ab initio" methods.

d Confirmed by electrochemical measurements of solutions/ melts.

with MAPLE (around 1951 at Münster University) our motto was always simply to "compare comparable compounds" and not to try to calculate step A using the $\mathrm{BHC}[5]$.

Practically, this means a restriction to reactions between binary compounds $(A, B)$ of the type 1) $m A_{\text {solid }}+n B_{\text {solid }}=p C_{\text {solid }}$ with $\Delta G_{298}^{\circ}$ "sufficiently small" [11], where $\Delta G_{298}^{\circ} \approx \Delta H_{298}^{\circ}$, including of course transformations between different modifications [12] of a given compound, but to be careful and sceptical with reactions including gaseous components like e.g. $\mathrm{SO}_{3 \mathrm{~g}}$ or typical "molecular" solids like $\mathrm{P}_{4} \mathrm{O}_{10}$.

\section{When and how to use MAPLE}

MAPLE can be calculated, when the arrangement of atoms as points in space and their charges are known. Now, the term "net charge" (as other related ones) is already in case of simple molecules without sense [13]. We need a clear concept of getting a substitution. Here we adopt the rather formal term "oxidation state" as charge. That means, we are restricted to those inorganic solids where this term is defined. A result of this "faking" is, that MAPLE in $\mathrm{kcal} / \mathrm{mol}$ resembles a currency (e.g. the ruble of the former USSR), which may be used in a given province quite properly, but without a generally accepted rate of exchange, if we try to connect it with "measured" thermodynamical properties like $\Delta H_{298}^{\circ}$. So in the following text we remain within our given province, comparing only what is comparable.

It is therefore extremely important always to remember that in writing formulas like $\mathrm{K}_{2}^{+}\left[\mathrm{S}^{6+} \mathrm{O}_{4}^{2-}\right]^{2-}$ we do not believe at all in the validity of such a formulation, e.g. in the corresponding "ionicity". But we are able to compare it with e.g. $\mathrm{Ba}^{2+}\left[\mathrm{S}^{6+} \mathrm{O}_{4}^{2-}\right]^{2-}$, etc.

\section{Why we use MAPLE}

\section{A) "Simple" Structures of Binary Compounds}

We have MAPLE $=\mathrm{MF} \cdot 331.81 \AA \mathrm{kcal} \mathrm{mol}{ }^{-1} / d_{1}$, where $\mathrm{MF}$ is the Madelung factor (a characteristic constant only, if no variable structural parameters like $x, y, z$ or $c / a$ etc. occur), $d_{1}$ (in $\AA$ ) the shortest distance between "cations and anions" and $331.81 \AA \mathrm{kcal} \mathrm{mol}^{-1}$ a factor, which delivers MAPLE in $\mathrm{kcal} / \mathrm{mol}$ [14]. In case of unknown compounds, we obtain e.g. MAPLE $\left(\mathrm{Fe}_{2} \mathrm{O}\right)$ using the rules of "additivity" of MAPLE, here 2 MAPLE $\left(\mathrm{A}_{3}\left[\mathrm{MO}_{2}\right]\right)-3 \operatorname{MAPLE}\left(\mathrm{A}_{2} \mathrm{O}\right)$ $=\operatorname{MAPLE}\left(\mathrm{M}_{2} \mathrm{O}\right)$ with $\mathrm{A}=\mathrm{K}, \mathrm{Rb}$, Cs and $\mathrm{M}=\mathrm{Fe}^{\mathrm{I}}$, $\mathrm{Co}^{\mathrm{I}}, \mathrm{Ni}^{\mathrm{I}}[15]$.

\section{B) Unusual Structures of Binary Compounds}

Already with binary compounds like $\mathrm{A}-\mathrm{La}_{2} \mathrm{O}_{3}$ and its fellowship we have curiosities. These have been studied recently in case of $\mathrm{Pr}_{2} \mathrm{O}_{3}$ [16] and $\mathrm{Ce}_{2} \mathrm{O}_{3}$ [17] via single crystal data (see Table 2). This is noteworthy, because looking at the Periodic Table of the Elements, on the "left side" of $\mathrm{La}_{2} \mathrm{O}_{3}$ we have $\mathrm{BaO}$ and on the "right" one $\mathrm{CeO}_{2}$ with conventional, simple structures of the $\mathrm{NaCl}$ - and $\mathrm{CaF}_{2}$-type, respectively.

The mutual Coordination Numbers (Table 2) show clearly, how unexpected the geometrical situation here is. If we would adopt this unexpected geometrical point of view only, one should write $(\mathrm{LaO})_{2} \mathrm{O}$ instead of $\mathrm{La}_{2} \mathrm{O}_{3}$. It is this, why here the concept of Bond Length/Bond Strength [18] as well as that of CHARDI 
(Charge Distribution in Solids) [19] must fail principally. But with the contributions of cations and anions to MAPLE there is no such outstanding situation! Table 3 explains the background of the similarity be-

Table 2. Motifs of mutual adjunction, shortest distances ${ }^{\mathrm{a}} d$ (in pm) and coordination numbers $(\mathrm{CN})$ for $\mathrm{La}_{2} \mathrm{O}_{3}{ }^{\mathrm{b}}$.

\begin{tabular}{lllll}
\hline & $1 \times \mathrm{O} 11$ & $1 \times \mathrm{O} 12$ & $1 \times \mathrm{O} 2$ & $\mathrm{CN}$ \\
\hline $1 \times \mathrm{La} 11$ & $3 / 3$ & $1 / 1$ & $3 / 3$ & $4+3$ \\
& $(237)$ & $(247)$ & $(272)$ & \\
$1 \times \mathrm{La} 12$ & $1 / 1$ & $3 / 3$ & $3 / 3$ & $4+3$ \\
$\mathrm{CN}$ & $(247)$ & $(237)$ & $(272)$ & \\
& 4 & 4 & 6 &
\end{tabular}

a $\bar{d}(\mathrm{O} 1-\mathrm{La})=2.39$ and $\bar{d}(\mathrm{O} 2-\mathrm{La})=2.72$ : unbelievable! The distances are calculated from lattice constants, adopting the nearly equal parameters from $\mathrm{Ce}_{2} \mathrm{O}_{3}[1983]$ and $\mathrm{Pr}_{2} \mathrm{O}_{3}$ [1985], where these discrepancies are proved.

b Here we change from the true space group $\mathrm{P} \overline{3} \mathrm{~m} 1$ to $\mathrm{P} \overline{1}$, writing $(\mathrm{La11})(\mathrm{La} 12)(\mathrm{O} 11)(\mathrm{O} 12)(\mathrm{O} 2)$. tween $\mathrm{MAP}(\mathrm{O} 1)(\mathrm{O} 1 \bumpeq \mathrm{O} 11$ and $\mathrm{O} 12)$ and $\mathrm{MAP}(\mathrm{O} 2)$ (since single crystal data exist for $\mathrm{Ce}_{2} \mathrm{O}_{3}$ and $\mathrm{Pr}_{2} \mathrm{O}_{3}$ only, we use here our data of $\operatorname{Pr}_{2} \mathrm{O}_{3}$ ):

a) the attractive interactions of $\mathrm{O} 11$ as well as $\mathrm{O} 12$ with $\operatorname{Pr} 11$ and $\operatorname{Pr} 12$ on one hand and of $\mathrm{O} 2$ with $\operatorname{Pr} 11$ and Pr12 on the other hand are not so different as the geometrical situation may indicate and

b) the small difference of $38 \mathrm{kcal} / \mathrm{mol}$ is additionally lowered by a stronger repulsion between $\mathrm{O} 11$ and O12, compared with the repulsion between the other anions.

\section{C) MAPLE of Different Modifications}

The example of the different known modifications of $\mathrm{TiO}_{2}$ (see Tables 4 and 5) confirms that the differences in MAPLE of these different structures of equal composition, like with $\Delta H_{298}^{\circ}$, are small, even then, when as in this case basically different geometrical

$$
\begin{aligned}
& \text { MAPLE }(\operatorname{Pr} 11)^{\mathrm{d}}:+3 \times 2 \sum \operatorname{Pr} 11 / \mathrm{O} 11 / / \sum \operatorname{Pr} 11 / \operatorname{Pr} 11=6 \times 107.0469=+642.281 \\
& +3 \times 2 \sum \operatorname{Pr} 11 / \mathrm{O} 12 / / \sum \operatorname{Pr} 11 / \operatorname{Pr} 11=6 \times 67.4010=+404.406 \\
& +3 \times 2 \sum \operatorname{Pr} 11 / \mathrm{O} 2 / / \sum \operatorname{Pr} 11 / \operatorname{Pr} 11=6 \times 84.0755=\frac{+504.445}{+1551.140} \\
& -3 \times 3 \sum \operatorname{Pr} 11 / \operatorname{Pr} 12 / / \sum \operatorname{Pr} 11 / \operatorname{Pr} 11=-9 \times 58.7848=-529.063 \\
& \Sigma=\overline{+1022.077^{\mathrm{c}}} \\
& \text { MAPLE(Pr12): analogous to MAP(Pr11) (same values) } \\
& \text { MAPLE(O11): } \quad+2 \times 3 \sum \mathrm{O} 11 / \operatorname{Pr} 11 / / \sum \mathrm{O} 11 / \mathrm{O} 11=6 \times 107.0469=+642.381 \\
& +2 \times 3 \sum \mathrm{O} 11 / \operatorname{Pr} 12 / / \Sigma \mathrm{O} 11 / \mathrm{O} 11=6 \times 67.4010=\frac{+404.406}{+1046.687} \\
& -2 \times 2 \sum \mathrm{O} 11 / \mathrm{O} 12 / / \sum \mathrm{O} 11 / \mathrm{O} 11=-4 \times 75.9228=-303.691 \\
& -2 \times 2 \sum \mathrm{O} 11 / \mathrm{O} 2 / / \sum \mathrm{O} 11 / \mathrm{O} 11=-4 \times 67.8059=\underline{-271.223} \\
& \Sigma=\frac{-574.914}{+471.772^{c}} \\
& \text { MAPLE(O12): analogous to MAP(O11) (same values) } \\
& \text { MAPLE(O2): } \quad+2 \times 3 \sum \mathrm{O} 2 / \operatorname{Pr} 11 / / \sum \mathrm{O} 2 / \mathrm{O} 2=6 \times 84.0755=+504.453 \\
& +2 \times 3 \sum \mathrm{O} 2 / \mathrm{Pr} 12 / / \sum \mathrm{O} 2 / \mathrm{O} 2 \\
& \begin{array}{l}
-2 \times 2 \sum \mathrm{O} 2 / \mathrm{O} 11 / / \sum \mathrm{O} 2 / \mathrm{O} 2 \\
-2 \times 2 \sum \mathrm{O} 2 / \mathrm{O} 12 / / \Sigma \mathrm{O} 2 / \mathrm{O} 2
\end{array} \\
& \begin{aligned}
=6 \times 84.0755 & =\frac{+504.453}{+1008.906} \\
=-4 \times 67.8059 & =-271.223 \\
=-4 \times 67.8059 & =\frac{-271.223}{-542.447} \\
\Sigma & =\frac{+466.458^{c}}{+4}
\end{aligned}
\end{aligned}
$$

a Here: space group $\mathrm{P} \overline{1},(\operatorname{Pr} 11)_{1}(\operatorname{Pr} 12)_{1}(\mathrm{O} 11)_{1}(\mathrm{O} 12)_{1}(\mathrm{O} 2)_{1}$. All sublattices are (like with $\mathrm{NaCl}$ ) commutative. All values in $\mathrm{kcal} / \mathrm{mol}$.

b Terms of interaction energies are written symbolically, e.g. $\mathrm{NaCl}$ : MAPLE $\left(\mathrm{Na}^{+}\right)=$ $1 \times 1 \sum \mathrm{Na} / \mathrm{Cl} / / \sum \mathrm{Na} / \mathrm{Na}$, and $\operatorname{MAPLE}\left(\mathrm{Cl}^{-}\right)=1 \times 1 \sum \mathrm{Cl} / \mathrm{Na} / / \sum \mathrm{Cl} / \mathrm{Cl}$ with e.g. $\operatorname{MAPLE}\left(\mathrm{Na}^{+}\right)=\frac{1}{2 d_{1}}\left[\left(6 \times \frac{1 \times 1}{\sqrt{1}}-5 \times \frac{1 \times 1}{\sqrt{2}}\right)+\left(-7 \times \frac{1 \times 1}{\sqrt{2}}+7 \times \frac{1 \times 1}{\sqrt{3}}\right)+\right.$ $\left.\left(1 \times \frac{1 \times 1}{\sqrt{3}}-1 \times \frac{1 \times 1}{\sqrt{4}}\right)^{2}+\ldots\right]$, so that including $1 \mathrm{Na}^{+}$from the left side we have $\mathrm{Na}_{6} \mathrm{Cl}_{6}, \mathrm{Na}_{13} \mathrm{Cl}_{13}, \ldots$, step by step, always $\mathrm{Na}_{n} \mathrm{Cl}_{n}$. Then and only then these series converge. In most textbooks this is formulated wrongly.

c The difference to the directly calculated contributions to MAPLE is very small: MAPLE $(\operatorname{Pr})=+1022.0764, \operatorname{MAPLE}(\mathrm{O} 1)=+471.7724, \operatorname{MAPLE}(\mathrm{O} 2)=+466.4583$, as expected. To show accuracy, so many numbers given.
Table 3. Analysis of MAPLE $\left(\operatorname{Pr}_{2} \mathrm{O}_{3}\right)^{\text {a }}$. 
arrangements are found. We know [20], that other modifications of $\mathrm{TiO}_{2}$ may exist; altogether it is an infinite number. It is easy to foresee, which ones basically could exist, but, as Tables 4 and 5 may indicate, completely impossible to make proposals for distances etc. This is confirmed by Figure 2 .

From the point of view of $\Delta H_{298}^{\circ}$, MAPLE and Mol.Vol. it seems quite unbelievable that these princi-
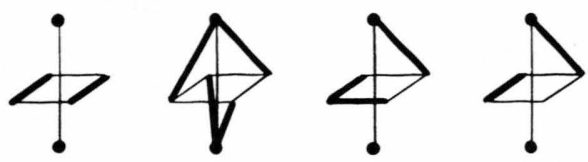

Fig. 2. $\mathrm{TiO}_{2}$ : Polyhedra of Coordination (P.C.). For (from left to right) Rutile, Anatase, Brookite, $\beta$-TiO ${ }_{2}$ (H.P.) it is schematically indicated how edges of P.C. are shared. Remember: every corner represents $1 \mathrm{O}^{2-}$, having 3 neighbours $\mathrm{Ti}^{4+}$, one in the center of the P.C. shown here, two in addition.

Table 4. Some data of the known modifications of $\mathrm{TiO}_{2}{ }^{\mathrm{a}}$.

\begin{tabular}{llllll}
\hline & Rutile & Anatase & Brookite & $\begin{array}{l}\beta \text {-TiO } \\
(\mathrm{HP})\end{array}$ & Units \\
\hline$\Delta H_{298}^{\circ}$ & -225.8 & -224.6 & -225.1 & & $\mathrm{kcal}^{\circ} / \mathrm{mol}$ \\
molar volume & 18.784 & 20.516 & 19.337 & 18.420 & $\mathrm{~cm}^{3}$ \\
$d(\mathrm{Ti}-\mathrm{O})_{1}{ }^{\mathrm{b}}$ & $194.7 \times 4$ & $193.4 \times 4$ & $186.3 \times 1$ & $187.4 \times 1$ & $\mathrm{pm}$ \\
$d(\mathrm{Ti}-\mathrm{Ti})_{1}$ & $295.8 \times 2$ & $303.9 \times 4$ & $295.0 \times 1$ & $308.8 \times 2$ & $\mathrm{pm}$ \\
$d(\mathrm{O}-\mathrm{O})_{1}$ & $253.3 \times 1$ & $246.6 \times 2$ & $249.5 \times 1^{\mathrm{c}}$ & $258.8 \times 1$ & $\mathrm{pm}$ \\
& & & $274.6 \times 1^{\mathrm{d}}$ & & \\
& & & $253.4 \times 1^{\mathrm{e}}$ & \\
\hline
\end{tabular}

a There are more modifications to be expected [20].

b $d(\ldots)_{1}$ is always the shortest distance of its sort.

c Here with $\mathrm{Ti}(\mathrm{O} 1)(\mathrm{O} 2)$ this is $d(\mathrm{O} 1-\mathrm{O} 1)_{1}$. ${ }_{\mathrm{d}} d(\mathrm{O} 2-\mathrm{O} 2)_{1}$.

e $d(\mathrm{O} 1-\mathrm{O} 2)_{1}$. pal geometrical differences between the modifications do not influence corresponding properties much more. Therefore already this simple quadruple is a general warning to overestimate obvious qualitative geometrical differences in solids of the same composition with respect to coexistence.

\section{D) MAPLE of Polynary Compounds}

40 years ago, we started to prove the theorem that MAPLE in case of polynary compounds is just the sum of MAPLE of the binary constituents. Now we know hundreds of such compounds where this holds, provided

1) all structures involved are "comparable",

2) there is no disorder!,

3) we restrict ourselves to halogenides and oxides of metals where $\Delta H_{298}^{\circ}$ (formation from binary components) is "small" [11],

4) we use for the contribution of components with typical molecule-like structures (indicating stronger covalent forces in small entities) values, which stem from related polynary compounds (e.g. MAPLE(" $\mathrm{P}_{2} \mathrm{O}_{5}$ ") or MAPLE("SO $\mathrm{S}_{3}$ ") from typical "solid" orthophosphates or sulfates [11]).

To save space, we discuss here, with respect to the already extended discussion of the modifications of $\mathrm{TiO}_{2}$, just $\mathrm{BaTiO}_{3}$, where some different modifications are known too. We expect that MAPLE $(\mathrm{BaO})+$ MAPLE $\left(\mathrm{TiO}_{2}\right)=\operatorname{MAPLE}\left(\mathrm{BaTiO}_{3}\right)$, because the heat of formation of $\mathrm{BaTiO}_{3}$ - as with many of its fellows -

Table 5. A complete analysis of MAPLE in case of the 4 known modifications of $\mathrm{TiO}_{2}$ (all values in $\mathrm{kcal} / \mathrm{mol}$ ).

\begin{tabular}{|c|c|c|c|c|c|c|c|c|c|}
\hline \multirow{3}{*}{$\begin{array}{l}\text { Interaction } \\
\sum \mathrm{Ti} / \mathrm{O} 1 / / \sum \mathrm{Ti} / \mathrm{Ti} \\
\sum \mathrm{Ti} / \mathrm{O} 2 / / \sum \mathrm{Ti} / \mathrm{Ti}\end{array}$} & \multirow{2}{*}{$\frac{\text { Charges }}{4 \times 2 \times}$} & \multicolumn{2}{|l|}{ Rutile } & \multicolumn{2}{|l|}{ Anatase } & \multicolumn{2}{|l|}{ Brookite } & \multicolumn{2}{|c|}{$\beta-\mathrm{TiO}_{2}(\mathrm{HP})$} \\
\hline & & 128.8609 & 1030.8872 & 127.6222 & 1020.9776 & 128.4782 & 1027.8256 & 129.5952 & 1036.7616 \\
\hline & $4 \times 2 \times$ & 128.8609 & 1030.8872 & 127.6222 & 1020.9776 & 128.0522 & 1024.4176 & 129.5952 & 1036.7616 \\
\hline & & & $\overline{2061.7792}$ & & $\overline{2041.9552}$ & & 2052.2432 & & 2073.5232 \\
\hline & & directly: & 2061.7790 & directly: & 2041.9553 & directly: & 2052.2437 & directly: & 2073.5231 \\
\hline \multirow{4}{*}{$\begin{array}{l}\sum \mathrm{O} 1 / \mathrm{Ti} / / \sum \mathrm{O} 1 / \mathrm{O} 1 \\
\sum \mathrm{O} 1 / \mathrm{O} 2 / / \Sigma \mathrm{O} 1 / \mathrm{O} 1\end{array}$} & $2 \times 4 \times$ & 113.0702 & 904.5616 & 127.6222 & 1020.9776 & 111.4060 & 891.2480 & 108.4770 & 867.8160 \\
\hline & $2 \times 2 \times$ & -77.0331 & -308.1324 & -102.9041 & -411.6164 & -73.3583 & -293.4332 & -68.8021 & -275.2084 \\
\hline & & & 596.4292 & & 609.3612 & & 597.8148 & & 592.6076 \\
\hline & & directly: & 596.4294 & directly: & 609.3612 & directly: & 597.8150 & directly: & 592.6077 \\
\hline \multirow{4}{*}{$\begin{array}{l}\sum \mathrm{O} 2 / \mathrm{Ti} / / \sum \mathrm{O} 2 / \mathrm{O} 2 \\
\sum \mathrm{O} 2 / \mathrm{O} 1 / / \Sigma \mathrm{O} 2 / \mathrm{O} 2\end{array}$} & $2 \times 4 \times$ & 113.0702 & 904.5616 & 127.6222 & 1020.9776 & 113.2888 & 906.3104 & 108.4770 & 867.8160 \\
\hline & $2 \times 2 \times$ & -77.0331 & -308.1324 & -102.9041 & -411.6164 & -75.6671 & -302.6684 & -68.8021 & -275.2084 \\
\hline & & & 596.4292 & & 609.3612 & & 603.6420 & & 592.6076 \\
\hline & & directly: & 596.4294 & directly: & 609.3612 & directly: & 603.6418 & directly: & 592.6077 \\
\hline MAPLE $\left(\mathrm{TiO}_{2}\right)$ & & & 3254.6 & & 3260.7 & & 3253.7 & & 3258.7 \\
\hline
\end{tabular}




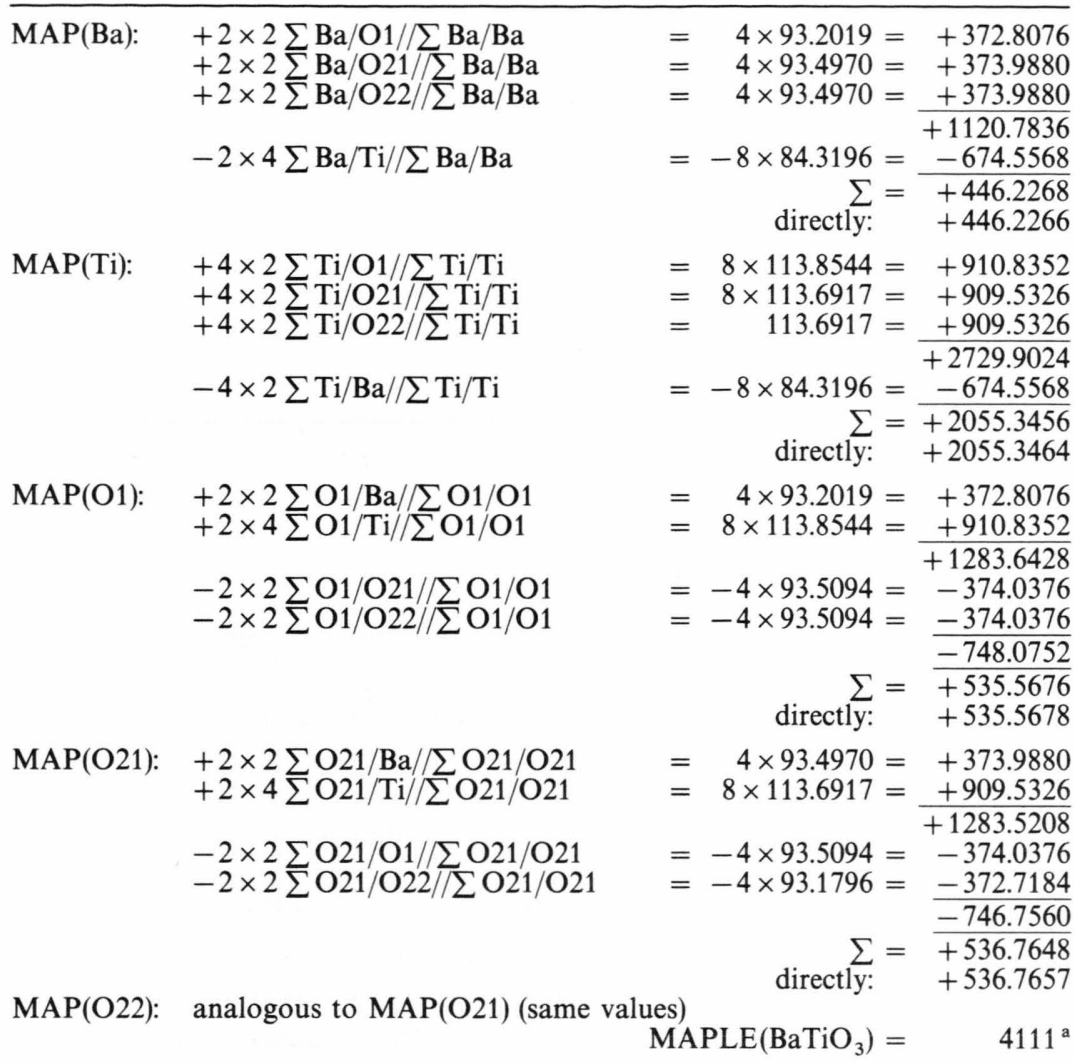

a $\operatorname{MAPLE}(\mathrm{BaO})+\operatorname{MAPLE}($ rutile $)=4092, \operatorname{MAPLE}\left(\mathrm{BaTiO}_{3}\right.$, hex. $)=4104$,

MAPLE $\left(\mathrm{BaTiO}_{3}\right.$, cub. $)=4095$, MAPLE $\left(\mathrm{BaTiO}_{3}\right.$, tetr. $)=4107 \mathrm{kcal} / \mathrm{mol}$.

by reaction of the binary compounds is small: $-37 \pm 2 \mathrm{kcal} / \mathrm{mol}$ for $\mathrm{BaTiO}_{3}$ (and e.g. $-46 \pm 3 \mathrm{kcal} /$ mol in case of $\mathrm{Ba}_{2} \mathrm{TiO}_{4}$ ).

Table 6 confirms the additivity in the well-ordered cases; cubic disordered $\mathrm{BaTiO}_{3}$ [1985] has been omitted, because the structure is not defined. Here we have a complete analysis of MAPLE $\left(\mathrm{BaTiO}_{3}\right)$ in case of the orthorhombic modification [1957], which shows the important facts as well as e.g. the crystallographically much more complicated case of hexagonal $\mathrm{BaTiO}_{3}=$ $(\mathrm{Ba} 1)_{1}(\mathrm{Ba} 2)_{2}(\mathrm{Ti1})_{1}(\mathrm{Ti} 2)_{2}(\mathrm{O} 1)_{3}(\mathrm{O} 2)_{6}$. We see:

1) The "dilution" of $\mathrm{TiO}_{2}$ with $\mathrm{BaO}$ leads to longer distances $d(\mathrm{Ti}-\mathrm{Ti})$ as a whole (Rutile: $d(\mathrm{Ti}-\mathrm{Ti})=$ $2.96(2 \times)$ and $3.57(2 \times) ; \mathrm{BaTiO}_{3}: d(\mathrm{Ti}-\mathrm{Ti})=$ $3.99(2 \times)$ and $4.01(4 \times)$, all other distances $d(\mathrm{Ti}-\mathrm{Ti})$ longer than $5.00 \AA)$ and so an increased attraction between $\mathrm{Ti} / \mathrm{O}(2730$ here and $2062 \mathrm{kcal} /$ mol with rutile) is observed, as expected.
Table 6. Complete analysis of MAPLE(BaTiO ${ }_{3}$ ) [1957] (orthorhombic, $A m m 2$, here triclinic in " $A 1$ "; all values in $\mathrm{kcal} / \mathrm{mol}$ ). 
stituents here may have. Because Ti still adopts the $\mathrm{CN}$ 6, but $\mathrm{CN}(\mathrm{Ba})$ is altered as well as those CN's of the ligands $\mathrm{O}$. Fortunately, we have $\mathrm{Ba}_{2}\left[\mathrm{TiO}_{4}\right]$ too, with tetrahedral anions and a $\mathrm{CN} 4$ without any doubt for Ti. And, in addition, two modifications have been investigated: With $\alpha-\mathrm{Ba}_{2}\left[\mathrm{TiO}_{4}\right]$ [1984], we have MAPLE $=4932 \mathrm{kcal} / \mathrm{mol}$, the difference to the sum of binary constituents is $4 \mathrm{kcal} / \mathrm{mol}$ (!), with $\beta$ - $\mathrm{Ba}_{2}\left[\mathrm{TiO}_{4}\right]$ [1973] the corresponding difference is $13 \mathrm{kcal} / \mathrm{mol}$, the fit is surprisingly good. But of course we know examples, where such differences are greater, when the change in $\mathrm{CN}$ is more dramatic. As a whole, this field of questions is not closed but still open.

\section{E) Consequences of the Theorem of Additivity of MAPLE}

Provided we are dealing with compounds of one family, then additional consequences appear. We discuss here just one:

In cases, where a corresponding binary oxide is structurally still insufficiently characterized, one can estimate the corresponding value of MAPLE quite easily and with high accuracy. We did this e.g. in case of $\mathrm{IrO}_{2}$. This oxide is known since a long time, surely it belongs to the rutile-type oxides, but yet never has been carefully studied with respect to its structure. We prepared lots of new oxoiridates of the alkali metals in form single crystals and know their structures quite well.

Surprisingly there are now two structurally completely different series of oxoiridates (IV), namely

a) the "common" ones with expected octahedra, $\mathrm{CN} 6$ $\mathrm{Li}_{8}\left[\mathrm{IrO}_{6}\right]$ [1986].

b) But there is a second series with unexpected planar groupings $\left[\mathrm{IrO}_{4}\right]^{4-}$, of composition $\mathrm{A}_{4}\left[\mathrm{IrO}_{4}\right]$ $(\mathrm{A}=\mathrm{Na}-\mathrm{Cs})$ and variants like $\mathrm{K}_{3}\left\{\mathrm{Li}\left[\mathrm{IrO}_{4}\right]\right\}[21]$, the first "litho-iridate" with chains of alternating squares (around Ir) and tetrahedra (around Li). These all show, again unexpected, an unusual magnetic behaviour, because they follow a CurieWeiss-law with $\mu=3.2 \mu_{\mathrm{B}}$, a value just between "high" and "low" spin. The reasons are still unknown. Mößbauer measurements are on the way.

Table 7 shows all known MAPLE values of oxoiridates. In certain disagreement with the situation for $\mathrm{BaTiO}_{3}$ and $\mathrm{Ba}_{2}\left[\mathrm{TiO}_{4}\right]$, cited above, there is a small difference between the proposed values for $\mathrm{IrO}_{2}$ using MAPLE of "normal" iridates (IV) with octahedral
Table 7. MAPLE and MAPLE("IrO ${ }_{2}$ ") for all known Oxoiridates(IV) in $\mathrm{kcal} / \mathrm{mole}$.

\begin{tabular}{|c|c|c|c|}
\hline Compound & MAPLE & MAPLE(“IrO ${ }_{2}$ ”) & Year \\
\hline \multicolumn{4}{|c|}{$\mathrm{CN}\left(\mathrm{Ir}^{4+}\right) 4$} \\
\hline $\begin{array}{l}\mathrm{Na}_{4}\left[\mathrm{IrO}_{4}\right] \\
\mathrm{K}_{2} \mathrm{Na}_{2}\left[\mathrm{IrO}_{4}\right] \\
\mathrm{K}_{3} \mathrm{Li}_{3}\left[\mathrm{IrO}_{4}\right] \\
\mathrm{K}_{4}\left[\mathrm{IrO}_{4}\right] \\
\mathrm{Rb}_{2} \mathrm{Na}_{2}\left[\mathrm{IrO}_{4}\right] \\
\mathrm{Rb}_{2} \mathrm{~K}_{2}\left[\mathrm{IrO}_{4}\right] \\
\mathrm{Rb}_{4}\left[\mathrm{IrO}_{4}\right] \\
\mathrm{Cs}_{2} \mathrm{Na}_{2}\left[\mathrm{IrO}_{4}\right] \\
\mathrm{Cs}_{4}\left[\mathrm{IrO}_{4}\right]\end{array}$ & $\begin{array}{l}4443.3 \\
4388.9 \\
4398.3 \\
4284.0 \\
4373.4 \\
4227.4 \\
4233.0 \\
4292.5 \\
4183.5\end{array}$ & $\begin{array}{l}3051.9 \\
3093.3 \\
3080.5 \\
3084.2 \\
3104.2 \\
3054.6 \\
3087.2 \\
3056.0 \\
3101.9\end{array}$ & $\begin{array}{l}{[1993]} \\
{[1994]} \\
{[1994]} \\
{[1985]} \\
{[1994]} \\
{[1986]} \\
{[1986]} \\
{[1992]} \\
{[1992]}\end{array}$ \\
\hline Mean value & & 3079.3 & \\
\hline \multicolumn{4}{|c|}{$\mathrm{CN}\left(\mathrm{Ir}^{4+}\right) 6$} \\
\hline $\begin{array}{l}\mathrm{Li}_{2} \mathrm{IrO}_{3} \\
\mathrm{Li}_{8} \mathrm{IrO}_{6} \\
\mathrm{CaIrO}_{3} \\
\mathrm{Ca}_{2} \mathrm{IrO}_{4} \\
\mathrm{BaIrO}_{3} \\
\mathrm{Ba}_{7} \mathrm{Ir}_{6} \mathrm{O}_{19} \\
\mathrm{Ba}_{4} \mathrm{Ir}_{3} \mathrm{O}_{10}\end{array}$ & $\begin{array}{r}3914.4 \\
6497.3 \\
4126.7 \\
5029.1 \\
3955.3 \\
24042.2 \\
12766.5\end{array}$ & $\begin{array}{l}3087.5 \\
3153.7 \\
3162.3 \\
3100.3 \\
3115.3 \\
3027.0 \\
3135.5\end{array}$ & $\begin{array}{l}{[1986]} \\
{[1992]} \\
{[1965]{ }^{*}} \\
{[1966]} \\
{[1991]} \\
{[1989]} \\
{[1991]}\end{array}$ \\
\hline Mean value & & 3110.4 & \\
\hline
\end{tabular}

* Film data only [22].

Mean value of all MAPLE(" $\mathrm{IrO}_{2}$ ") is: MAPLE(" $\mathrm{IrO}_{2}$ ") = $3092.9 \mathrm{kcal} / \mathrm{mole}$.

polyhedra of coordination, and those, which form the subfamily of type $\mathrm{A}_{4}\left[\mathrm{IrO}_{4}\right]$ and their quaternary derivatives (Table 8) with planar coordination.

Within this last group, additivity again is observed. Starting with e.g. $\mathrm{K}_{4}\left[\mathrm{IrO}_{4}\right]$ and $\mathrm{Na}_{4}\left[\mathrm{IrO}_{4}\right]$, we expect for $\mathrm{K}_{2} \mathrm{Na}_{2}\left[\mathrm{IrO}_{4}\right] 4364$ instead of the "real" value $4389 \mathrm{kcal} / \mathrm{mol}$, and for $\mathrm{Rb}_{2} \mathrm{Na}_{2}\left[\mathrm{IrO}_{4}\right]$ from $\mathrm{Rb}_{4}\left[\mathrm{IrO}_{4}\right]$ and $\mathrm{Na}_{4}\left[\mathrm{IrO}_{4}\right] 4338$ instead of "real" $4373 \mathrm{kcal} / \mathrm{mol}$, the differences of $0.5 \%$ and $0.9 \%$ correspond to normal deviations of $\pm 1 \%$ of such estimations.

\section{On MAPLE of a Double Iodide, $\mathrm{Cs}_{2} \mathrm{Li}_{3} \mathrm{I}_{5}[23]$}

All examples discussed before were oxides of metals. But of course with halogenides we have a quite similar situation. We consider here just one example, the cited iodide. Table 9 shows the motifs of mutual adjunction and distances $d(\mathrm{M}-\mathrm{I})$ of the binary constituents, Table 10 compares contributions to MAPLE. We see:

- with distances, Li2 is the "big winner", adopting here $\mathrm{CN} 4$, (observed with LiI in an unstable form only [1956] in thin films)

- remarkably short are the distances $d(\operatorname{Li} 2-\mathrm{I})$, while $d($ Li1-I) all are elongated compared with LiI. 


\begin{tabular}{|c|c|c|c|c|c|}
\hline Compound & MAPLE & MAPLE $_{\text {binary }}$ & $\Delta$ & MAPLE “binary” & $\Delta^{\prime}$ \\
\hline $\mathrm{Na}_{4} \mathrm{IrO}_{4}$ & 4443.3 & 4612.9 & $\begin{array}{l}-169.6 \\
(-3.68 \%)\end{array}$ & 4484.3 & $\begin{array}{l}-41.0 \\
(-0.91 \%)\end{array}$ \\
\hline $\mathrm{K}_{2} \mathrm{Na}_{2}\left[\mathrm{IrO}_{4}\right]$ & 4388.9 & 4517.1 & $\begin{array}{c}-128.2 \\
(-2.84 \%)\end{array}$ & 4388.5 & $\begin{array}{l}+\mathbf{0 . 4} \\
(+0.01 \%)\end{array}$ \\
\hline $\mathrm{K}_{3} \mathrm{Li}\left[\mathrm{IrO}_{4}\right]$ & 4398.3 & 4539.3 & $\begin{array}{l}-141.0 \\
(-3.11 \%)\end{array}$ & 4410.7 & $\begin{array}{l}-12.4 \\
(-0.28 \%)\end{array}$ \\
\hline $\mathrm{K}_{4}\left[\mathrm{IrO}_{4}\right]$ & 4282.0 & 4421.3 & $\begin{array}{c}-137.3 \\
(-3.11 \%)\end{array}$ & 4292.7 & $\begin{array}{l}-8.7 \\
(-0.20 \%)\end{array}$ \\
\hline $\mathrm{Rb}_{2} \mathrm{Na}_{2}\left[\mathrm{IrO}_{4}\right]$ & 4373.4 & 4490.1 & $\begin{array}{c}-116.7 \\
(-2.60 \%)\end{array}$ & 4361.5 & $\begin{array}{l}+\mathbf{1 1 1 . 9} \\
(+0.27 \%)\end{array}$ \\
\hline $\mathrm{Rb}_{2} \mathrm{~K}_{2}\left[\mathrm{IrO}_{4}\right]$ & 4227.4 & 4394.3 & $\begin{array}{c}-167.0 \\
(-3.80 \%)\end{array}$ & 4265.7 & $\begin{array}{c}-38.3 \\
(-0.90 \%)\end{array}$ \\
\hline $\mathrm{Rb}_{4}\left[\mathrm{IrO}_{4}\right]$ & 4233.0 & 4367.3 & $\begin{array}{c}-134.3 \\
(-3.08 \%)\end{array}$ & 4238.7 & $\begin{array}{l}-5.7 \\
(-0.13 \%)\end{array}$ \\
\hline $\mathrm{Cs}_{2} \mathrm{Na}_{2}\left[\mathrm{IrO}_{4}\right]$ & 4292.5 & $4458.0^{*}$ & $\begin{array}{l}-165.7 \\
(-3.72 \%)\end{array}$ & $4329.4 *$ & $\begin{array}{l}-36.9 \\
(-0.85 \%)\end{array}$ \\
\hline \multirow[t]{2}{*}{$\mathrm{Cs}_{4}\left[\mathrm{IrO}_{4}\right]$} & 4183.5 & $4303.1 *$ & $\begin{array}{c}-119.7 \\
(-2.79 \%)\end{array}$ & $4174.5^{*}$ & $\begin{array}{l}+9.0 \\
(+0.22 \%)\end{array}$ \\
\hline & & \multicolumn{2}{|c|}{$\sum|\Delta|=1279$} & \multicolumn{2}{|c|}{$\sum|\Delta|=164$} \\
\hline
\end{tabular}

Table 8. MAPLE of Oxoiridates(IV) with $\mathrm{CN}\left(\mathrm{Ir}^{4+}\right) 4$ compared with MAPLE binary and MAPLE “binary" respectively; MAPLE in $\mathrm{kcal} / \mathrm{mole}$.

* For MAPLE $\left(\mathrm{Cs}_{2} \mathrm{O}\right)$ the value for hypothetically cubic $\mathrm{Cs}_{2} \mathrm{O}$ (anti $\mathrm{CaF}_{2}$-type) was taken.

Table 9. Motifs of mutual adjunction of $\mathrm{Cs}_{2} \mathrm{Li}_{3} \mathrm{I}_{5}$ [1983]. Distances and MEFIR in pm.

\begin{tabular}{|c|c|c|c|c|c|c|}
\hline & $1 \times \mathrm{I} 1$ & $2 \times I 2$ & $2 \times I 3$ & $\mathrm{CN}$ & $\mathrm{ECoN}^{\mathrm{a}}$ & MEFIR $^{b}$ \\
\hline $2 \times \mathrm{Cs}$ & $\begin{array}{l}2 / 4 \\
(382)\end{array}$ & $\begin{array}{l}1 / 1+2 / 2 \\
(384)(394)\end{array}$ & $\begin{array}{l}2 / 2+1 / 1 \\
(387)(430)\end{array}$ & $7+1$ & 7.7 & 169 \\
\hline $1 \times$ Li1 & - & $\begin{array}{l}4 / 2 \\
(318)\end{array}$ & $\begin{array}{l}2 / 1 \\
(320)\end{array}$ & 6 & 6.0 & $99^{c}$ \\
\hline $2 \times \operatorname{Li} 2$ & $\begin{array}{l}1 / 2 \\
(278)\end{array}$ & $\begin{array}{l}1 / 1 \\
(275)\end{array}$ & $\begin{array}{l}2 / 2 \\
(275)\end{array}$ & 4 & 4.0 & $55^{\mathrm{c}}$ \\
\hline $\mathrm{CN}$ & 6 & 6 & 6 & & & \\
\hline ECoN & 6.0 & 6.0 & 5.7 & & & \\
\hline MEFIR & 216 & 220 & 222 & & & \\
\hline
\end{tabular}

a Effective CN [24].

b Ionic Radius $R\left(\mathrm{I}^{-}\right)=220 \mathrm{pm}$ was used as starting value for the determination of the Mean Fictive Radii, MEFIR [24], with the subprogram FIT/FIT of program MAPLE.

c Notice the incredible difference in distances and correspondingly in MEFIR.

- distances $d(\mathrm{Cs}-\mathrm{I})$ remain practically unaltered, compared with CsI.

Table 10 delivers the contributions to MAPLE, which reflect finely the geometrical situation as a whole. Here MAPLE of the binary iodides are com-
Table 10. Comparison of MAPLE contribution with $\mathrm{Cs}_{2} \mathrm{Li}_{3} \mathrm{I}_{5}$ and the binary constituents $(\mathrm{kcal} / \mathrm{mol})$.

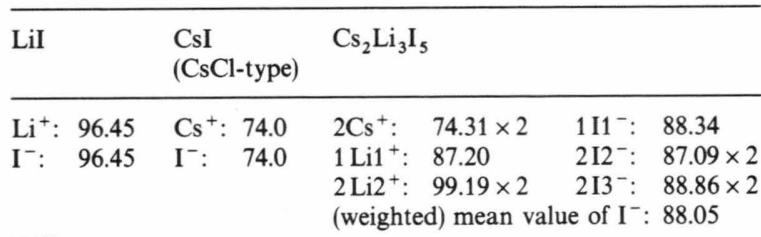

ences $^{\mathrm{a}}$ : $\mathrm{Cs}^{+}:+0.31 \times 2 \quad 2 \times$ MAPLE$(\mathrm{CsI})+3 \times$ MAPLE$(\mathrm{LiI})=874.5$ $\mathrm{Li1}^{+}:-9.25 \times 1 \quad \operatorname{MAPLE}\left(\mathrm{Cs}_{2} \mathrm{Li}_{3} \mathrm{I}_{5}\right)=874.4$ $\mathrm{Li}^{+}:+2.74 \times 2$

a MAPLE(ternary)-MAPLE(binary).

pared with MAPLE $\left(\mathrm{Cs}_{2} \mathrm{Li}_{3} \mathrm{I}_{5}\right)$ :

- $\mathrm{Cs}^{+}$retains its MAPLE value,

- Li1 loses and Li2 wins a little bit and

- winners of the game, related to the weighted average of MAPLE $\left(\mathrm{I}^{-}\right)$of the ternary iodide, so to speak, are the two $\mathrm{I}^{-}$"supplied" by CsI (with $2 \times 14 \mathrm{kcal} / \mathrm{mol}$ ), while "those of Lil" lose $(3 \times 8 \mathrm{kcal} / \mathrm{mol})$, and

- in summary MAPLE of the ternary iodide corresponds exactly to the sum of MAPLE of the binary halogenides, 874.5/874.4 
The structure is very unexpected:

- First we have the irregular polyhedron of coordination (CP) of $\mathrm{Cs}^{+}$: Cs on top of an irregular pentagon with a triangle as a cap, forming layers parallel to (100),

- the octahedra of Li1/I forming infinite chains along [010] via two common edges (basical motif of rutile), and

- the tetrahedra $\left[\mathrm{Li} 2 / \mathrm{I}_{4}\right]$ are building pairs via a common corner, which form infinite double chains, again via cor-

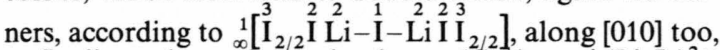
- so finally we have alternating layers $\left(\mathrm{Cs}^{+}\right)_{2}$ and $\left(\mathrm{Li}_{3} \mathrm{I}_{5}\right)^{2-}$ parallel to (010) and:

- in addition this exact agreement with MAPLE.

Remember, both iodides MI are of simple structure, and yet, the structure of the ternary iodide is so complicated, that no simple formulation exists indicating the main features of the constitution. Notice, how difficult it is to express such relatively simple geometrical relations using a chemical formula. A weak attempt: $\mathrm{Cs}_{2(010)}^{2 / \infty}\left(\mathrm{Li}_{3}\left\{{ }_{1 / \infty 00]}\left[\mathrm{I}_{2 / 2}^{3}\left(\mathrm{I} \mathrm{Li}^{2}-\mathrm{I}-\mathrm{Li} \mathrm{I}^{2}\right) \mathrm{I}_{2 / 2}^{3}\right]\right\}\right)$ - barely decipherable!

\section{On MAPLE with Hydrates of "Inorganic Salts"}

a) There exists a vast number of "salt hydrates". Many have been elucidated by X-rays. But to find the positions of $\mathrm{H}^{+}$accurately, hydrates with $\mathrm{D}_{2} \mathrm{O}$ should be investigated by neutron diffraction. The number of such examples is limited.

b) To compare with the components, we need appropriately "exact" refined structures of the corresponding anhydrous salts (another limitations) as well as MAPLE of $\mathrm{D}_{2} \mathrm{O}$. Unfortunately in case of most modifications of ice, disorder reigns the structure. But since 1984 we have now with $\mathrm{D}_{2} \mathrm{O}$ (ice-8) a standard, (almost) without any disorder.

c) So now MAPLE can be applied here too. What influence might the differences in "hydrogen bridges" have? Table 11 gives 3 examples:

- With $\mathrm{SrCl}_{2} \cdot 2 \mathrm{D}_{2} \mathrm{O}$, interactions $\mathrm{D} \ldots \mathrm{Cl}$ should be rather small. So interactions $\mathrm{O}-\mathrm{D}$... O, already present with $\mathrm{D}_{2} \mathrm{O}$, are counting in this hy- drate only. They are obviously counterbalancing exactly: the agreement between MAPLE(Hydrate) with the MAPLE sum of binary constituents is perfect.

- $\mathrm{CaSO}_{4} \cdot 2 \mathrm{H}_{2} \mathrm{O}$ is "just a hydrate"; industrially important, yet not a "complex" in common meaning. But here of course, additional interactions $\mathrm{O}-\mathrm{H} \ldots \mathrm{O}-\mathrm{SO}_{3}$ are expected. Nevertheless, again the agreement is perfect (neutron diffraction powder data).

- A typical complex in the sense of Werner is $\left[\mathrm{Ni}\left(\mathrm{OD}_{2}\right)_{6}\right]\left[\mathrm{SO}_{4}\right]$, here to be formulated (as already the examples before) ionic: $\left[\mathrm{Ni}^{2+}\left(\mathrm{O}^{2-} \mathrm{D}_{2}^{+}\right)_{6}\right]^{2+}$ $\cdot\left[\mathrm{S}^{6+} \mathrm{O}_{4}^{2-}\right]^{2-}$. We know by experience with hundreds of MAPLE calculations of polynary compounds, that within a limit of $\Delta \pm 1 \%$ we have "good" agreement. So here too we are within the common limits of deviation.

Once again dealing with "faked currency, but staying within our province" in comparing comparables, MAPLE works. Of course, in nearly all cases, where the positions of $\mathrm{H}^{+}$have been located by simple X-ray investigations, we have disagreement, because here almost always we have $d(\mathrm{O}-\mathrm{H})$ $\sim 0.7-0.8 \AA$, because it is not $\mathrm{H}^{+}$but the density maximum of the bond $\mathrm{O}-\mathrm{H}$ which has been located.

Such complexes as $\left[\mathrm{Ni}\left(\mathrm{OD}_{2}\right)_{6}\right]\left[\mathrm{SO}_{4}\right]$ are of course far away from concepts like Bond Length/Bond Strength and similar ones like CHARDI, - and all other hydrates too. This is, because $d(\mathrm{O}-\mathrm{H}) \sim 100 \mathrm{pm}$, and the range of lengths of so-called "hydrogen bridges" $\mathrm{O}-\mathrm{H} \ldots \mathrm{O}$ (normally $d(\mathrm{O}-\mathrm{O})=220 \ldots 300 \mathrm{pm}$ ) show that the next-but-one neighbours of $\mathrm{H}^{+} / \mathrm{D}^{+}$are much further away than $40 \%$ of the "normal bond length". Then these neighbours are not to be counted. Otherwise the $\mathrm{CN}$ of a densest packing of spheres would remarkably exceed the "visible" value of 12 , $\mathrm{Na}^{+}$in $\mathrm{NaCl}$ would have a much greater $\mathrm{CN}$ as 6 , etc. Extreme examples of this sort are "addition compounds" with crown ethers and other very big neutral organic ligands of inorganic salts, e.g. with $\mathrm{LiCl}$. What happens here with the lattice energy $E_{L}$ is still open for discussion.

\begin{tabular}{|c|c|c|c|c|c|}
\hline \multicolumn{2}{|c|}{$\mathrm{SrCl}_{2} \cdot 2 \mathrm{D}_{2} \mathrm{O}[1993]$} & \multicolumn{2}{|c|}{$\mathrm{CaSO}_{4} \cdot 2 \mathrm{H}_{2} \mathrm{O}[1982]$} & \multicolumn{2}{|c|}{$\mathrm{NiSO}_{4} \cdot 6 \mathrm{D}_{2} \mathrm{O}[1990]$} \\
\hline $\mathrm{SrCl}_{2}[22]$ & 553.4 & $\mathrm{CaSO}_{4}[1980]$ & 8232.4 & $\mathrm{NiSO}_{4}[1990]$ & 8381.5 \\
\hline $2 \mathrm{D}_{2} \mathrm{O}[1984]$ & $2 \times 1220.8$ & $2 \mathrm{H}_{2} \mathrm{O}^{\mathrm{a}}$ & $2 \times 1220.8$ & $6 \mathrm{D}_{2} \mathrm{O}$ & $6 \times 1220.8$ \\
\hline$\Sigma=$ & 2995.0 & $\Sigma=$ & 10674.0 & $\Sigma=$ & 15706.2 \\
\hline obs. & 2998.2 & obs. & 10691.2 & obs. & 15813.5 \\
\hline$\Delta=$ & +3.2 & $\Delta=$ & +17.2 & $\Delta=$ & +107.3 \\
\hline$\hat{=}$ & $+0.1 \%$ & $\hat{=}$ & $+0.2 \%$ & $\hat{=}$ & $+0.7 \%$ \\
\hline
\end{tabular}

Table 11. MAPLE of hydrates (kcal/mol).

a Supposition: MAPLE(ice8, $\left.\mathrm{H}_{2} \mathrm{O}\right)=$ MAPLE(ice8, $\mathrm{D}_{2} \mathrm{O}$ ). 
MAPLE in case of Polynary Compounds with at least one molecular-like Binary Component

Here MAPLE generally fails. Typical examples are already carbonates, sulfates and phosphates. But there is another possibility to use MAPLE:

Like with the oxoiridates mentioned above, one can use "increments", derived e.g. like $\operatorname{MAPLE}\left(\mathrm{Cs}_{2} \mathrm{CO}_{3}\right)-$ $\operatorname{MAPLE}\left(\mathrm{Cs}_{2} \mathrm{O}\right)=\operatorname{MAPLE}$ (“CO $\mathrm{CO}_{2}$ ”). In case of orthophosphates, we have shown long ago, including a large number of well characterized phosphates containing $\left[\mathrm{PO}_{4}\right]^{3-}$, how properly this works [25]. Correspondingly we deal with e.g. perchlorates, permanganates, because $\mathrm{Mn}_{2} \mathrm{O}_{7}, \mathrm{Cl}_{2} \mathrm{O}_{7}$ etc. have molecules as entities of the crystal.

Surprisingly there are exceptions. For e.g. MAPLE $\left(\left(\mathrm{SeCl}_{3}\right)^{+}\left[\mathrm{AuCl}_{4}\right]^{-}\right)$we have good agreement with the sum of MAPLE $\left(\mathrm{SeCl}_{4}\right)$ and MAPLE $\left(\mathrm{AuCl}_{3}\right)$. This holds for $\left(\mathrm{PCl}_{4}\right)^{+}\left[\mathrm{AuCl}_{4}\right]^{-}$too, where MAPLE $\left(\mathrm{PCl}_{5}\right)$ is used. But, here the solid is structurally $\left(\mathrm{PCl}_{4}\right)^{+}\left[\mathrm{PCl}_{6}\right]^{-}$and "salt like". More investigations on a broader base are needed here, urgently; see Part 2 of this work.

\section{Limits of the Concept of MAPLE}

What has been discussed before indicates clearly that MAPLE should be used generally only, if and when the term Oxidation State can be used unambiguously. Organic compounds and related ones like metal organics of course are omitted. By using increments like MAPLE(" $\mathrm{P}_{2} \mathrm{O}_{5}$ ") [26] even those compounds, where covalency dominates with at least one of the binary components, are available for such considerations, too.

If we regard that field of Inorganic Solid State Chemistry as a "sphere" where the concept of MAPLE holds, then between the "sphere" and the "outer-space" (organic materials etc.) there is a more or less small "atmosphere", where MAPLE could be applied by help of increments in the sense mentioned. But it is important to note that there is another limitation, - so to speak, with the "nucleus" of this sphere. An example is illustrating this: The structure of $\mathrm{SmZrF}_{7}$ [1973] was first reported to be space group $\mathrm{P} 2{ }_{1}$. A thorough re-investigation indicated distances $d(\mathbf{F}-\mathbf{F})=213 \mathrm{pm}$, obviously too short, and led last not least (using new X-ray data) to space group P2 $1 /$ c. But the change in MAPLE is very small, from $3629\left(\mathrm{P} 2_{1}\right)$ to $3630 \mathrm{kcal} / \mathrm{mol}\left(\mathrm{P} 2_{1} / \mathrm{c}\right)$ for $\mathrm{SmZrF}_{7}$ [1994], because the structure as a whole is practically unaltered. The same holds for isotypic $\mathrm{EuSnF}_{7}$ [1992] with
MAPLE $=3703$, adopting the wrong space group $\mathrm{P} 2{ }_{1}$, while with $\mathrm{P} 2{ }_{1} / \mathrm{c}$ we obtained $3705 \mathrm{kcal} / \mathrm{mol}$ for $\mathrm{EuSnF}_{7}$ [1994].

So to speak, the concept gets "blinded" when the differences of the corresponding atomic arrangements are too small. We know this since 1977 from the example of $\mathrm{Ba}_{2}\left[\mathrm{CuF}_{6}\right]$ (space group $\mathrm{B}$ bam [1973]) and a reinvestigation (space group C mca [1977]), the first based on single crystal X-ray and the second based on neutron diffraction powder data. As already said before, it is the uncertainty of $\Delta= \pm 1 \%$ which indicates this "nucleus of blindness" of our concept.

\section{An Incidental Remark}

We now know the weak points of BHC,

1) to shift all difficulties into step $B 3$,

2) the multiple choices connected with the non-defined term "energy of complex formation" of step B3,

3) the "deadly" fact that not only $X^{2-}(\mathrm{O} \ldots \mathrm{Te})$ and $\mathrm{X}^{3-}(\mathrm{N} . .$.$) , but "nearly all" of chemically impor-$ tant "anions", known from solutions, melts and crystal structures, with charges $\neq-1$ like $\left[\mathrm{CO}_{3}\right]^{2-},\left[\mathrm{BO}_{3}\right]^{3-},\left[\mathrm{SiO}_{4}\right]^{4-}$ etc. are "completely unstable" and not "catchable" even by "real" ab initio calculations.

\section{Questions:}

1) What can we use instead of $\mathrm{BHC}$ ? Helping chemists to answer this question is a business of physical chemistry/physics.

2) Is it possible, to transfer the "faked" currency of MAPLE values into "thermochemical dollars" $(\mathrm{kcal} / \mathrm{mol})$ ? This problem is still open. Help is needed, urgently, too.

3) Is the spectrum of applications of MAPLE, shown here in principle, all what we can do? Can we use MAPLE for quite other considerations? One answer to 3 ) is already being tested:

\section{On Systematics of Inorganic Solid State Chemistry}

What we know or at least believe to know in this given field of chemistry presents an overwhelming disorder of so called "facts". The mixture is, unfortunately for its use, extremely inhomogeneous. Just two examples might show the difficulties: 
With Werner's ideas, which changed the world of inorganic chemistry dramatically, $\mathrm{K}_{2}\left[\mathrm{PtCl}_{6}\right]$ is forever connected. But we cannot calculate its MAPLE and compare it with the constituents, because $\mathrm{PtCl}_{4}$ even today is structurally not characterized! But in addition, doubts are connected with well known structures, too. Is e.g. the baryte-type of $\mathrm{BaSO}_{4}$ based on intimate twinning and therefore wrong?

\section{How can we order the Multiplicity of Known Structures of Inorganic Solids?}

For sure, just to know, even if knowledge can be obtained by applying "scientific" and complicated methods only, is

- a prestate of science in the literal sense only,

- insufficient in looking in case of new compounds for "related" ones, because of the uncertainty of what "related" might mean,

- uneconomical. Time and money could be saved if we would really know not only what is "known", but where relations are hidden e.g. by different formulas.

What does order mean? For sure not the alphabetical one, used nowadays in textbooks, Structure Reports or Chemical Abstracts, within more or less arbitrarily chosen chapters.

Order in a preliminary form might be such one, with which Linné once started (exaggerated: "every animal able to fly is a bird") - and which even in its modern form is object of very critical discussions.

\section{MAPLE as a Tool in Ordering Structures}

1) What does the term "sulfate" mean? Examples tell us: Oxides like $\mathrm{Na}_{2}\left[\mathrm{SO}_{4}\right], \mathrm{Mg}\left[\mathrm{SO}_{4}\right]$ or $\mathrm{Al}_{2}\left[\mathrm{SO}_{4}\right]_{3}$ are for good reasons regarded as "sulfates". But the next member in this series, $\mathrm{Si}\left(\mathrm{SO}_{4}\right)_{2}$, is still unknown despite all investigations.

2) $\mathrm{SO}_{3}$ (solid) is neither in form of $\left(\mathrm{SO}_{3}\right)_{n}$ nor $\left(\mathrm{SO}_{3}\right)_{3}$ a sulfate, e.g. in the sense of $\left(\mathrm{SO}_{2}\right)^{2+}\left[\mathrm{S}_{2} \mathrm{O}_{7}\right]^{2-}$ or $\left(\mathrm{S}_{2} \mathrm{O}_{5}\right)^{2+}\left[\mathrm{SO}_{4}\right]^{2-}$ etc., for sure.

3) Consequently, the still unknown oxide $\mathrm{P}_{2} \mathrm{O}_{5} \cdot 5 \mathrm{SO}_{3}$ definitely could not adopt a constitution like $\mathrm{P}_{2}\left[\mathrm{SO}_{4}\right]_{5}$, - but what in case of e.g. $\mathrm{P}_{2} \mathrm{O}_{5} \cdot \mathrm{SO}_{3}$ with $\left(\mathrm{P}_{2} \mathrm{O}_{4}\right)^{2+}\left[\mathrm{SO}_{4}\right]^{2-}$ ? Nobody knows, and no profound guess seems possible. So, is $\mathrm{SiS}_{2} \mathrm{O}_{8}$ $\left(\hat{=} \mathrm{Si}\left[\mathrm{SO}_{4}\right]_{2}\right.$ ?) really a sulfate?
Table 12. MAPLE variants of $\mathrm{Li}_{2} \mathrm{CO}_{3}[1980](\mathrm{kcal} / \mathrm{mol})$.

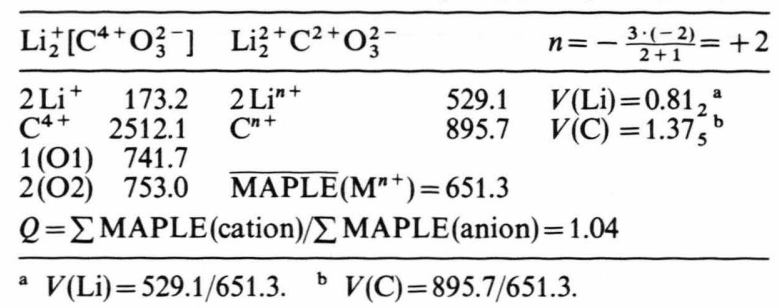

So long MAPLE has been used, starting with sufficiently exact known structures, using oxidation states as charges of "points in space". This assumption is arbitrary. Here now we use MAPLE calculated for those charges, which are equal for every "point" of the structure occupied by cations, e.g. instead of $\mathrm{Na}_{2}^{+}\left[\mathrm{S}^{6+} \mathrm{O}_{4}^{2-}\right]$ now $\mathrm{Na}_{2}^{8 / 3+} \mathrm{S}^{8 / 3+} \mathrm{O}_{4}^{2-}$. With respect to compounds like $\mathrm{La}_{2} \mathrm{OS}_{2}$ or $\mathrm{Gd}_{2} \mathrm{NCl}_{3}$ etc. we do not alter the assumed charge of $\mathrm{O}^{2-}$ or $\mathrm{Gd}$, to make comparisons of comparable compounds still possible.

\section{Examples:}

Table 12 compares $\mathrm{Li}_{2}^{+}\left[\mathrm{C}^{4+} \mathrm{O}_{3}^{2-}\right]$ with $\mathrm{Li}_{2}^{2+} \mathrm{C}^{2+} \mathrm{O}_{3}^{2-}$, concerning MAPLE. We notice the exciting changes and find the expected value for $Q \sim 1$, because $\mathrm{M}_{3}^{2+} \mathrm{O}_{3}^{2-}$ corresponds more or less to $\mathrm{MO}$, and for e.g. $\mathrm{MgO}$ we have $Q=1(\mathrm{NaCl}$-type). The values of $V$, e.g. $V\left(\mathrm{Li}^{n+}\right)=\operatorname{MAPLE}\left(\mathrm{Li}^{2+}\right) / \operatorname{MAPLE}\left(\mathrm{M}^{n+}\right)$ and $V\left(\mathrm{C}^{n+}\right)$ confirm that in the sense of Werner surely $\mathrm{C}$ is to be regarded as the "builder of the complex" and $\mathrm{Li}$ as the accompanying "cation".

It is important to note that nevertheless we are leaving Werner's point of view here. Following him, every chloride $\mathrm{A}_{2}\left[\mathrm{PtCl}_{6}\right]$ is first and at all a "hexachloroplatinate", independently of what ever the cation A might be, the role of this is just to deliver "neutrality" of the charges of ions (involved, e.g. in aqueous solution). Here, with $V\left(\mathrm{M}^{n+}\right)$, we regard every constituent as a "member in the same class of the collective" and ask how its importance for the building of the complex from the point of view of $V$ might be.

Table 13 supplies us with a typical "double chalcogenide" in the classical sense (a thio-spinel). With all spinels, the prehistory of the starting materials, the temperature, time and other conditions of heating during synthesis at elevated temperatures as well as the cooling process etc. influences the more or less different crystallographic situation (order/disorder of 
Table 13. MAPLE variants of $\mathrm{MgAl}_{2} \mathrm{~S}_{4}[1993](\mathrm{kcal} / \mathrm{mol})\left(\right.$ spinel; $\mathrm{S}^{2-}$ : hex. closest packing of spheres: $\mathrm{Mg}^{[6]}(\mathrm{Al} 1)^{[4]}(\mathrm{Al} 2)^{[6]} \mathrm{S}_{4} \hat{=}$ $\mathrm{Mg}^{2+}(\mathrm{A} 11)^{3+}(\mathrm{A} 12)^{3+} \mathrm{S}_{4}^{2-} ;(\mathrm{M} 1)^{n+}(\mathrm{M} 2)^{n+}(\mathrm{M} 3)^{n+} \mathrm{S}_{4}^{2-} ; n=-\frac{4 \cdot(-2)}{1+2}=\frac{3}{8}$.

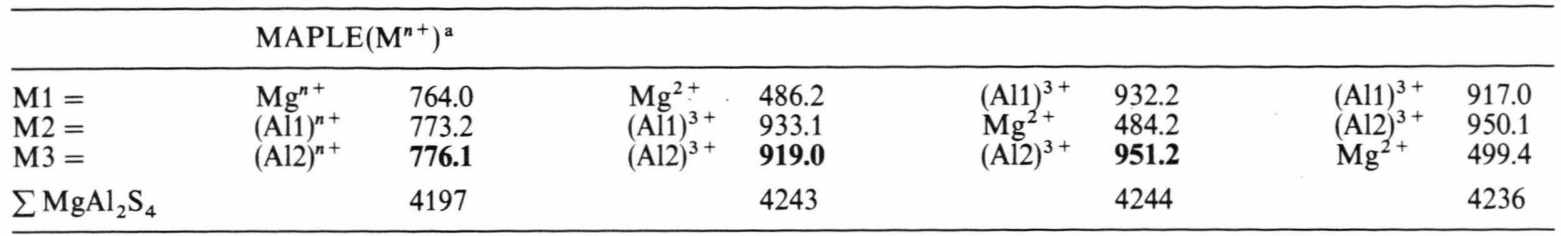

a $V\left(\mathrm{Mg}^{n+}\right)=0.99_{1} ; V\left(\mathrm{Al1}^{n+}\right)=1.00_{3} ; V(\mathrm{Al} 2)=1.00_{7} ;$ compare Table 12 for $V$.

cations). Table 13 explains such experimental difficulties plainly, just with a glance!

A corresponding example with fluorides is $\mathrm{LiSbF}_{6}$ [1962]: Writing $\mathrm{Li}^{3+} \mathrm{Sb}^{3+} \mathrm{F}_{6}^{-}$, we have MAPLE contributions of $1007(\mathrm{Li}) / 1097(\mathrm{Sb}) \mathrm{kcal} / \mathrm{mol}$ with $V\left(\mathrm{Li}^{n+}=0.96\right.$ and $V\left(\mathrm{Sb}^{n+}\right)=1.04$. It is really a double fluoride, simply $\mathrm{LiSbF}_{6}$, not $\mathrm{Li}\left[\mathrm{SbF}_{6}\right]$.

On borderline of "double oxides" is e.g. ilmenite, $\mathrm{MgTiO}_{3}$ [1989] with MAPLE $1227\left(\mathrm{Mg}^{n+}\right) / 1262$ $\left(\mathrm{Ti}^{n+}\right) \mathrm{kcal} / \mathrm{mol}$ and $V\left(\mathrm{Mg}^{n+}\right)=0.91, V\left(\mathrm{Ti}^{n+}\right)=1.09$. Here: $n=+3$.

Based on many examples to be mentioned in Part 2 of this paper, we state that

- every partner with $V\left(\mathrm{M}^{n+}\right)>1$ is important as a "center of complex formation";

- every time, we find $0.9<V\left(\mathrm{M}^{n+}\right)<1.0$, we regard this as typical for "double" oxides, halogenides etc.; - and that all "common" cations in the sense of Werner (like $\mathrm{K}^{+}$in case of $\mathrm{K}_{2}\left[\mathrm{PtCl}_{6}\right]$ are characterized by $V\left(\mathrm{M}^{n+}\right)<0.9$. The lower the value of $V$ then, the more is this partner "just a cation".

So Table 14 gives a typical example of a sulfate, where $\mathrm{Li}^{+}$already indicates partially a "double salt character" with $\left[\mathrm{SO}_{4}\right]^{2-}$. Table 15 shows two typical "lithooxometalates". In case of e.g. $\mathrm{K}_{4} \mathrm{Li}\left[\mathrm{IO}_{6}\right]$ we have tetrahedral coordination with $\mathrm{Li}^{+}$, accompanied by formation of chains $\mathrm{K}_{4} \underset{\infty}{1}\left(\mathrm{Li}\left[\mathrm{O}_{2}\left(\mathrm{IO}_{2}\right) \mathrm{O}_{2}\right]\right)$, where "trans-edges" of two octahedra $\left[\mathrm{IO}_{6}\right]$ form simultaneously corresponding "trans-edges" of the tetrahedron around $\mathrm{Li}$.

Last but not least Table 16 illustrates two examples of the very rare case of oxides where a metal with given oxidation state forms side by side anions of different $\mathrm{CN}$. It is still open for discussion why no groupings $\left[\mathrm{O}_{4} \mathrm{MOMO}_{4}\right]$ occur here. For a detailed discussion compare next chapter.
Table 14. MAPLE $\left(\mathrm{KNaLi}_{2}\left[\mathrm{SO}_{4}\right]_{2}\right) \quad$ [1987] in $\mathrm{kcal} / \mathrm{mol}$ $(n=16 / 6=8 / 3+; Q=1.34)^{\mathrm{a}}$.

\begin{tabular}{|c|c|c|c|}
\hline MAPLE(K) & 663 & $V\left(\mathrm{M}^{n+}\right)=0.65_{8}{ }^{\mathrm{a}}$ & lower limit for $\mathrm{A}^{+}$ \\
\hline$(\mathrm{Na})$ & 799 & $0.79_{3}$ & \\
\hline (Li1) & 938 & $0.93_{1}$ & "double oxide" \\
\hline (Li2) & 907 & $0.90_{1}$ & \\
\hline (S1) & 1354 & $1.34_{4}$ & "complex builder" \\
\hline$(\mathrm{S} 2)$ & 1384 & $\left.1.37_{4}\right\}$ & \\
\hline
\end{tabular}

a For $Q$ and $V$ see Table 12 .

Table 15. MAPLE of two typical "litho"-oxometallates (kcal/mol). For $V$ compare Table 12.

\begin{tabular}{|c|c|c|c|c|c|}
\hline \multicolumn{3}{|c|}{ A) $\begin{array}{l}\mathrm{KLi}_{6}\left[\mathrm{BiO}_{6}\right][1991] \\
n=\frac{-6 \cdot(-2)}{8}=1.5\end{array}$} & \multicolumn{3}{|c|}{ B) $\begin{array}{r}\mathrm{K}_{4} \mathrm{Li}\left[\mathrm{IO}_{6}\right][1988] \\
n=\frac{-6 \cdot(-2)}{6}=2\end{array}$} \\
\hline & MAPLE & $V\left(\mathrm{M}^{n+}\right)$ & & MAPLE & $V\left(\mathrm{M}^{n+}\right)$ \\
\hline $\begin{array}{l}\mathrm{K}^{n+} \\
6 \mathrm{Li}^{n+} \\
\mathrm{Bi}^{n+}\end{array}$ & $\begin{array}{l}165.6 \\
318.6 \\
402.1\end{array}$ & $\begin{array}{l}0.53_{4} \\
1.02_{8} \\
1.29_{7}\end{array}$ & $\begin{array}{l}(\mathrm{K} 1)^{n^{+}} \\
(\mathrm{K} 2)^{n+} \\
(\mathrm{K} 3)^{n+} \\
(\mathrm{K} 4)^{n+} \\
\mathrm{Li}^{n+} \\
\mathrm{I}^{n+}\end{array}$ & $\begin{array}{l}403.0 \\
365.4 \\
380.0 \\
369.7 \\
570.0 \\
835.5\end{array}$ & $\begin{array}{l}0.82_{7} \\
0.75_{0} \\
0.78_{0} \\
0.75_{9} \\
1.17_{0} \\
1.71_{5}\end{array}$ \\
\hline \multicolumn{3}{|c|}{ so we write: $\mathrm{K}\left(\mathrm{Li}_{6}\left[\mathrm{BiO}_{6}\right]\right)$} & \multicolumn{3}{|c|}{$\mathrm{K}_{8} \propto\left[1\left(\mathrm{O}_{2 / 2}\left(\mathrm{IO}_{2}\right) \mathrm{O}_{2} \mathrm{LiO}_{2 / 2}\right)_{2}\right.$} \\
\hline
\end{tabular}

Table 16. MAPLE $(\mathrm{kcal} / \mathrm{mol})$ of $\mathrm{CsK}_{5}\left[\mathrm{Ru}^{v} \mathrm{O}_{5}\right]\left[\mathrm{Ru}^{v} \mathrm{O}_{5}\right]$ and $\mathrm{Rb}_{6}\left[\mathrm{Te}^{v} \mathrm{O}_{4}\right]\left[\mathrm{Te}^{v} \mathrm{O}_{5}\right]-2$ examples with two congenital anions of different $\mathrm{CN}(n=-9 \cdot(-2) / 8=9 / 4$ for both).

\begin{tabular}{|c|c|c|c|c|c|}
\hline \multicolumn{3}{|c|}{$\mathrm{CsK}_{5} \mathrm{Ru}_{2} \mathrm{O}_{9}[1992]$} & \multicolumn{3}{|c|}{$\mathrm{Rb}_{6} \mathrm{Te}_{2} \mathrm{O}_{9}[1990]$} \\
\hline & MAPLE & $V\left(\mathrm{M}^{n+}\right)$ & & MAPLE & $V\left(\mathrm{M}^{n+}\right)$ \\
\hline $\begin{array}{l}\mathrm{Cs}^{n+} \\
1(\mathrm{~K} 1)^{n+} \\
2(\mathrm{~K} 2)^{n+} \\
2(\mathrm{~K} 3)^{n+} \\
{[4](\mathrm{Ru} 1)^{n+}} \\
{ }^{[5]}(\mathrm{Ru} 2)^{n+}\end{array}$ & $\begin{array}{l}441.2 \\
463.6 \\
490.4 \\
503.6 \\
937.0 \\
892.7\end{array}$ & $\begin{array}{l}0.74_{7} \\
0.78_{5} \\
0.83_{1} \\
0.85_{3} \\
1.58_{7} \\
1.51_{3}\end{array}$ & $\begin{array}{l}(\mathrm{Rb} 1)^{n+} \\
(\mathrm{Rb} 2)^{n+} \\
(\mathrm{Rb} 3)^{n+} \\
{ }^{44]}(\mathrm{Te} 1)^{n+} \\
{ }^{[5]}(\mathrm{Te} 2)^{n+}\end{array}$ & $\begin{array}{l}444.9 \\
482.2 \\
470.0 \\
880.6 \\
925.6\end{array}$ & $\begin{array}{l}0.77_{4} \\
0.83_{8} \\
0.81_{7} \\
1.53_{2} \\
1.61_{0}\end{array}$ \\
\hline
\end{tabular}




\section{Closing Remarks}

1) The weakness of BHC in case of a sufficiently accurate calculation of $E_{\mathrm{L}}$ is evident:

- we try to calculate a number $(\mathrm{kcal} / \mathrm{mol})$ for $E_{\mathrm{L}}$, which results as a relatively small difference of big contributions of different sorts;

- but much more "deadly" is the complete nonexistence of most of the typical inorganic anions as gaseous species with a charge exceeding $n=1$ in case of the mononuclear entities $\mathbf{M}^{n-}$ and $\left[\mathrm{ML}_{\mathrm{p}}\right]^{n-}$, and probably all of dinuclear analogues etc. too. Even with $n=1$, ions like $\left[\mathrm{BO}_{2}\right]^{-}$ or $\left[\mathrm{AlO}_{2}\right]^{-}$, well known as gas species, have so far never been found in solid state chemistry -

[1] H.-Chr. Gaebell, G. Meyer, and R. Hoppe, Z. anorg. allg. Chem. 498, 94 (1983).

[2] M. Jansen and R. Hoppe, Z. anorg. allg. Chem. 417, 31 (1975).

[3] e.g. Gmelin Handbook of Inorganic Chemistry is critical, but not "up to date", and data banks like that of Chemical Abstracts are neither critical nor "complete".

[4] e.g. solid $\mathrm{KAl}\left(\mathrm{SO}_{4}\right)_{2} \cdot 12 \mathrm{H}_{2} \mathrm{O}$ is structurally a complex, its chemical behaviour in aqueous solution corresponds to a "double salt" - so, where do we place it?

[5] R. Hoppe, Angew. Chem. 78, 52 (1966); Angew. Chem. Int. Ed. Engl. 5, 95 (1966); Adv. Fluor. Chem. 6, 387 (1970); Izvj. Jugoslav. Centr. Krist. (Zagreb) 8, 21 (1973); R. Hoppe in Crystal Structure and Chemical Bonding in Inorganic Chemistry, North Holland Publ. Comp., Amsterdam 1975, p. 127.

[6] A. Werner, Z. anorg. allg. Chem. 3, 267 (1893), 8, 153 (1895).

[7] Even in case of noble gases there is no "closed form" of theory of such interactions between atoms.

[8] See e.g. T. C. Waddington, Advances in Inorganic Chemistry, Vol. 1, Academic Press, New York 1959, pp. $158 \mathrm{ff}$.

[9] e.g. my discussions with Prof. Klixbüll Jorgensen concerning $\Delta H_{298}^{\circ}\left(\mathrm{O}_{\mathrm{g}}^{2-}\right)$, how to overcome this handicap already started in 1951 - no chance!

[10] Compare e.g. R. Janoschek, Z. anorg. allg. Chem. 616, 101 (1992)

[11] With typical examples we have $(\mathrm{kcal} / \mathrm{mol})$
a) $\mathrm{BaO}_{\text {solid }}+\mathrm{SiO}_{2 \text { solid }}=\mathrm{BaSiO}_{3 \text { solid }}$, $\Delta H_{298}^{\circ}=-38( \pm 1)$
b) $2 \mathrm{BaO}_{\text {solid }}+\mathrm{SiO}_{2 \text { solid }}=\mathrm{Ba}_{2} \mathrm{SiO}_{4 \text { solid }}$, $\Delta H_{298}^{\circ}=-65( \pm 1)$,
c) $3 \mathrm{KF}_{\text {solid }}^{298}+\mathrm{AlF}_{3 \text { solid }}=\mathrm{K}_{3} \mathrm{AlF}_{6 \text { solid }}, \Delta H_{298}^{\circ}=-18( \pm 2)$, in general: $-\Delta H_{298}^{\circ} / n<15 \mathrm{kcal} /$ ligand of the polynary compound; $n=$ number of ligands of anion.
But counterexamples are:
d) $\mathrm{Cs}_{2} \mathrm{O}_{\text {solid }}+\mathrm{CrO}_{3 \text { solid }}=\mathrm{Cs}_{2} \mathrm{CrO}_{4 \text { solid }}$, $\Delta H_{298}^{\circ}=-127( \pm 6)$,
e) $\mathrm{Cs}_{2} \mathrm{O}_{\text {solid }}+\mathrm{SO}_{3 \text { solid }}=\mathrm{Cs}_{2} \mathrm{SO}_{4 \text { solid }}$, $\Delta H_{298}^{\circ}=-160( \pm 15)$.

Please note the limited accuracy of $\Delta H_{298}^{\circ}$-values. they form dimers, oligomers, rings, chains, layers or 3-dimensional networks.

2) Nevertheless, MAPLE, using "oxidation states" as "charges" of points in space, which indicate "cations" and "anions" of polynary compounds, is very useful in comparing new compounds with related fellows already known.

3) Last not least, the missing possibility to order the ocean of known halogenides and chalcogenides, including even nitrides as e.g. $\mathrm{Gd}_{2} \mathrm{NCl}_{3}$, may be found in a first preliminary form, as sketched in the closing part of this communication, by using MAPLE in a new sense. This will be discussed more intimately in demonstrating more examples in a Part 2 of this paper, published later.

Here the "additivity of MAPLE" does not hold. But of course using MAPLE(" $\mathrm{CrO}_{3}$ ") or MAPLE(" $\mathrm{SO}_{3}$ "), derived from well known simple structures via e.g. MAPLE $\left(\mathrm{BaCrO}_{4}\right)-\operatorname{MAPLE}(\mathrm{BaO})=\operatorname{MAPLE}\left(“ \mathrm{CrO}_{3}\right.$ ”), once again the concept of addivity of MAPLE works.

[12] Normally due to the lack of thermochemical measurements a decision between "form" and "modification" is difficult.

[13] There is no legitimate advice where to "cut" e.g. the bond $\mathrm{Si}-\mathrm{F}$ of the molecule $\mathrm{SiF}_{4}$, and therefore no "effective charge". The same holds for so-called "electrondensity-maps", which in addition are faked by other things.

[14] We follow here the old custom with MAPLE in using $\mathrm{kcal} / \mathrm{mol}$ instead of $\mathrm{kJ} / \mathrm{mol}$ as well as the different sign with respect $\Delta H_{\mathrm{T}}^{\circ}[5]$.

[15] W. Burow, J. Birx, F. Bernhardt, and R. Hoppe, Z. anorg. allg. Chem. 619, 923 (1993); F. Bernhardt and R. Hoppe, Z. anorg. allg. Chem. 619, 969 (1993).

[16] R. Wolf and R. Hoppe, Z. anorg. allg. Chem. 529, 61 (1985); a reinvestigation yielded $z(\mathrm{O} 1)=0.647$ in complete agreement with [17]; M. Serafin and R. Hoppe (1994, yet unpublished).

[17] H. Bärnighausen and G. Schiller, J. Less-common Met. 110, 385 (1985).

[18] N. E. Breese and M. O'Keefe, Acta Cryst. B47, 192 (1991).

[19] R. Hoppe, St. Voigt, H. Glaum, J. Kissel, H.-P. Müller, and K. Bernet, J. Less-common Met. 156, 105 (1989).

[20] R. Hoppe and J. Köhler, Z. Kristallogr. 183, 77 (1988).

[21] K. Mader and R. Hoppe, J. Alloys and Comp. 206, 271 (1994). This is the key citation to all other iridates $\mathrm{A}_{4}\left[\mathrm{IrO}_{4}\right]$.

[22] G. Brauer and M. Knausenberger, Z. anorg. allg. Chem. 320, 54 (1963).

[23] G. Meyer and H.-C. Gaebell, Mat. Res. Bull. 18, 135 (1983).

[24] R. Hoppe and G. Meyer, Z. anorg. allg. Chem. 420, 40 (1976); R. Hoppe, Z. Kristallogr. 150, 213 (1979).

[25] R. Hoppe and M. Serafin, unpublished; compare M. Serafin, diploma thesis, Gießen 1976. 